Rev. Tadeusz Zadykowicz Katolicki Uniwersytet Lubelski Jana Pawła II

\title{
The Moral Dimension of Patriotism
}

A complete description of patriotism must be multifaceted and include moral aspects. Specifically, a theological and moral approach to patriotism must first define the patriotic duty to love one's homeland, the source of this love, and its concrete manifestations, and then morally assess (anti)patriotic attitudes. The source of patriotic duty is faith, hope, and the universal and ordered love that pertains to the Fourth Commandment. Patriotic duty is manifested in specific attitudes that demonstrate one's affective disposition and practical service for the good of one's homeland. Everything that opposes patriotism (i.e., its absence, distortion, or outright anti-patriotism) is a serious moral offense. The central character of love in Christian morality serves as the grounds for this evaluation.

Key words: homeland, patriotism, morality.

\section{Introduction}

Only a multifaceted examination of the question of one's homeland and patriotism from biblical, philosophical, historical, pedagogical, psychological, sociological, and legal perspectives makes a complete description of this phenomenon possible. Since patriotism has a moral dimension, moral theologians reflect on this issue. A theological and moral approach to one's homeland and patriotism should be integrated, meaning that such an approach should consider the biblical (the source of love for one's homeland), philosophical (the value of one's homeland), sociological (the context of and changes in patriotic attitudes), pedagogical (patriotic education), and legal (the responsibility 
Moral theology

to manifest patriotic attitudes and fulfill patriotic duties) aspects of patriotism. From a theological and moral point of view, these three issues concerning patriotism are the most important: patriotic duty, concrete ways of realizing patriotism, and a moral assessment of (anti) patriotic attitudes.

Patriotism is a relatively new topic in moral theology. Since the Fathers of the Church have written about patriotism, it is a question proper to all ages. ${ }^{1}$ However, in general the Church has provided instruction on patriotism only occasionally throughout history. In later times, particularly during the seventeenth century when the field of moral theology began to develop, the topic of patriotism practically did not exist. It was not until the end of the nineteenth century and throughout the twentieth century that moral theologians began to reflect on patriotism as a moral duty. For example, if one searches for studies that include "patriotism in the teaching of the Church" (these studies are numerous and even written by moral theologians ${ }^{2}$ ), it appears that this topic appears for the first time in the nineteenth and twentieth centuries. The oldest reference to patriotism in the Polish bishop's 2017 letter entitled Chrześcijanski ksztatt patriotyzmu (The Christian Form of Patriotism) comes from Pope Pius X's Encyclical on St. Anselm Aosta: Communium Rerum (1909). In addition, Pope Leo XIII's teachings mention the subject sometimes. ${ }^{3}$

The reason for theologians' lack of interest in patriotism is twofold. First, before the Second Vatican Council, an extreme verticalism dominated the Christian worldview. As a consequence, the Christian moral life was directed toward the pursuit of a goal that lay outside of temporal reality - namely, union with Christ. Therefore, the focus was not on the temporal reality, to which patriotism belongs. Second, the extreme individualism that arose from medieval nominalism inclined theologians to perceive man as an individual before God, concerned

1 St. Ambrose is the first spokesman for love for one's homeland, on which he based his arguments for engaging in a just war. St. Augustine-St. Ambrose's great student-and others have based their just war theories on St. Ambrose's concept of love for one's homeland.

2 See P. Przesmycki, "Patriotyzm w nauczaniu Kościoła katolickiego," Annales. Etyka w życiu gospodarczym 11, no. 2 (2008): 195-203; J. Salij, Patriotyzm dzisiaj (Poznan: W Drodze, 2005); J. Pawłowicz, Patriotyzm jako podstawa ładu społecznego w nauczaniu Kościoła katolickiego, http://www.kuria-dodatek. szczecin.opoka.org.pl/patriotyzm.htm (Accessed: 06.01.2017); B. Niemiec, "Patriotyzm," in Jan PawetII. Encyklopedia nauczania społecznego, ed. A.Zwoliński (Radom: Wydawnictwo Polwen, 2003), 353. 
for the salvation of his own soul and enmeshed in his own conscience. This individualistic morality emphasized striving for one's own salvation, perfecting oneself, and seeking sanctity at the cost of one's relationships with others; therefore, patriotism, which considers man's relationship to his homeland and fellow citizens, precludes such individualism. However, the (post-)consiliar "theology of temporal reality," which placed particular value on social problems in moral theology, led to a theological revival that considered the value of one's homeland and patriotism in documents from the Second Vatican Council, ${ }^{4}$ the Catechism of the Catholic Church, ${ }^{5}$ papal teaching, as well as statements from national conferences of Catholic bishops. ${ }^{6}$ In this regard, John Paul II's teachings directed toward Poles" as well as his "Address to the United Nations" in 1995 are particularly rich. ${ }^{8}$

\section{The Duty to Love One's Country}

In order to discuss the moral aspects of patriotism, it is necessary to first generally define this concept. All dictionaries, encyclopedias, and moral theology textbooks define patriotism as love for one's country. ${ }^{9}$ Consequently, patriotism is an attitude of respect, love, and self-

$4 \quad$ See Second Vatican Council, Decree on the Mission Activity of the Church: Ad gentes divinitus (Vatican City, Italy: Libreria Editrice Vaticana, 1965),15; Paul VI, Pastoral Constitution on the Church in the Modern World: Gaudium et spes (Vatican City, Italy: Libreria Editrice Vaticana, 1965), 75.

5 See Catechism of the Catholic Church (Vatican City, Italy: Libreria Editrice Vaticana, 1997), 2199, 2212, 2239-2242, 2310. Hereafter abbreviated as CCC.

6 In 1972 and 2017, the Polish Conference of Catholic Bishops published two letters, respectively, dedicated solely to the topic of patriotism.

7 See T. Zadykowicz, "O nowe oblicze patriotyzmu. Refleksja nad nauczaniem Jana Pawła II do Polaków,” Roczniki Teologiczne, Vol. 52, no. 3 (2005): 145-157.

John Paul II, "Address to the United Nations," The Fiftieth General Assembly of the United Nations Organization, October 5, 1995, United Nations Headquarters, New York. Speech.https://w2.vatican.va/content/john-paul-ii/en/speeches/1995/ october/documents/hf_jp-ii_spe_05101995_address-to-uno.html.

See J. Bartyzel, “Patriotyzm,” Encyklopedia katolicka, Vol. 15, ed. E. Gigilewicz (Lublin: 2011); H. Skorowski, Być chrześcijaninem i obywatelem dziś. Refleksje o postawach moralno-spotecznych (Warsaw: 1994), 55; D. Kluxen-Pyta, "Patriotismus," Lexikon für Theologie und Kirche, eds. K. Baumgartner (Freiburg, Basel, Rome, Vienna: 1998), 1470; T. Zadykowicz, "Patriotyzm jako postawa," Etyka żotnierska. Etyka w stużbie ojczyźnie, eds. K. Jeżyna, J. Gałkowski, and M. Kalinowski (Warsaw: Wydawnictwo Ministerstwa Obrony Narodowej, 2008), 55; T.Zadykowicz, "Umiłowanie ojczyzny i patriotyzm," Etyka żotnierska. Etyka w stużbie ojczyźnie, eds. K. Jeżyna, J. Gałkowski, and M. Kalinowski (Warsaw: Wydawnictwo Ministerstwa Obrony Narodowej, 2008): 76. 
Moral theology

sacrifice for one's homeland. Patriotism makes one ready to defend his country at all times and is an expression of the value one places on his homeland and all that comprises it: the people, heritage, history, tradition, territory, and language. Put differently, if one's "homeland" is the country of one's origin, history, tradition, common heritage, and citizenship, then one's recognition of the values of this country and the acceptance of the good of its elements are the basis of patriotism. It is difficult to disagree with these definitions of patriotism. However, today's situation proves that it is necessary to continually seek objective criteria for the good of one's country, since patriotism is not only a person's subjective feeling that he is serving his country. For the purpose of this study, this article assumes that, generally speaking, patriotism is love for one's homeland and one's response to the value that is his homeland.

Patriotic love is a duty. What, however, is the source of this duty? A moral theologian would assert that the source of patriotic duty lies in faith, love, hope, and the Fourth Commandment. ${ }^{10}$ From a moral and theological point of view, the issue of patriotism lies in the context of faith and love (especially familial love, which pertains to the Fourth Commandment). For Christians, patriotic love for one's homeland flows from and is motivated by faith, which makes it possible to fully perceive the value of the role that one's earthly homeland plays in his attainment of the heavenly homeland. In a certain sense, hope is also a source of patriotism because waiting for the attainment of one's "heavenly homeland" demands an active involvement in developing and transforming one's earthly homeland. After all, man would not be capable of expressing any form of patriotism if he did not trust and hope in the effectiveness of his efforts.

Patriotism is also inscribed in the command to love one's neighbor. ${ }^{11}$ The love of Christ is universal and embraces all peoples without exception. However, this does not exclude the priority and privilege to love those closest to us. In this sense, Pope Pius XII taught that "legitimate and well-ordered love of our native country should not make us close our eyes to the all-embracing nature of Christian Charity, which calls for consideration of others and of their interests in the pacifying light

10 Other sources (political, social, etc.) also speak of man's patriotic duty, but the theoretical scope of this article is limited to theology.

11 See Polish Conference of Catholic Bishops, Letter Chrześcijański ksztatt patriotyzmu, no. 1 (March 14, 2017). 
of love." 12 This ultimately means that patriotism should be included in the complete order of love (ordo caritatis) — an order that prescribes love of all people, but gives precedence to those who are closest by virtue of particular bonds (familial, societal, etc.) Since parents are those closest to a given person, and since one's homeland is in a certain sense like a mother, patriotic duties flow from the Fourth Commandment of the Decalogue. ${ }^{13}$ Therefore, one's relationship to one's homeland is analogous with familial love, particularly the love of a son (child) for his mother.

The duty to love one's country is universal, and no one should speak against his homeland. However, the concrete ways in which an individual carries out his patriotic duty depend on many factors, including the role a person plays in society. If the essence of love is a free gift of oneself and the responsible acceptance of this gift on the part of another, then both committed politicians and ordinary citizens should engage in this particular exchange of gifts and, thereby, fulfill their duty towards their homeland.

\section{Expressions of Patriotism}

As mentioned previously, patriotism arises from the value that each citizen places on his homeland. Love is the most appropriate response to something or someone that a person values. In other words, a person loves something or someone because he finds value in this person or thing. Therefore, the first patriotic duty arises from love and is manifested in and conditioned by discovering those things that are inherently valuable in and comprise the idea of one's homeland-namely, the nation, its heritage, history, traditions, territory, and language. A person is not a true patriot unless he has said the following about his homeland: "This is my mother."14 This saying contains not only doctrinal elements-for example, the definition of the very essence

12 See Pius XII, Encyclical on the Unity of Human Society: Summi Pontificatus (Vatican City, Italy: Libreria Editrice Vaticana, 1939), 49.

13 See CCC, 2199.

14 In a homily that John Paul II gave in Kielce, Poland on June 3, 1991, he perfectly expressed this mother-son relationship with one's country: “...this land is my mother! This Homeland is my mother! These are my brothers and sisters! And understand this, you all who thoughtlessly approach these matters, understand that it is impossible for these matters not to affect me, and it is impossible for them not to pain me! They should pain you too! It is easy to destroy, but more difficult to rebuild. Our homeland has been destroyed for too long! It is time to intensively rebuild it!" 
Moral theology

of patriotism-but also the emotions that a patriotic individual feels toward his country. ${ }^{15}$

Patriotism entails a strong emotional attitude toward one's country, just as a son feels strongly for his mother. One should love and honor his country as he does his mother. This is why the normal feelings that one experiences with regard to the land of his family and youth as well as his appreciation of family customs are an expression of patriotism. Even memories of how much one has received from his homeland; gratitude for what one has received; a joyful response to one's country's successes; and participation in the cares of one's country out of concern for one's homeland are a testament to a person's patriotism. The Polish bishops' letter conveys such "emotional" elements when it speaks about local patriotism with regards to one's "dear" homeland which is "the color of heaven and the shape of the landscape of a particular place. And we recognize her [homeland's] face in the faces and fates of those with whom we live each day." 16

The various emotions that a person feels toward his homeland should incite him to pray for his nation; for, prayer is the best and most universal expression of love and gratitude for that which one has received from his homeland in the past as well as for the blessings one will receive in the future. Such prayer should be public and involve all citizens, matters, and areas of life, both good and bad. A true patriot's prayers should express his total interest in the matters concerning his homeland, including its past, present, and future problems and successes.

While patriotism manifests itself in prayer for the good of one's homeland, ${ }^{17}$ the fullness of patriotism demands that citizens actively strive for the true good of their homeland, not an apparent or particular good. Moreover, a true patriot equates the good of the homeland with his own good, not vice versa. While it is impossible to list all of

15 In previous articles, the author analyzes John Paul II's greeting and farewell speeches that he gave during his pilgrimages to his homeland. Such analysis proved that these speeches are particularly interesting with regard to how they address the topic of patriotism; for, they contain not only doctrinal content, but also the Pope's own patriotic feeling as someone who had to live most of his life in a country far away from is homeland. See T. Zadykowicz, O nowe oblicze patriotyzmu, 145-157.

No. 5.

In a speech he gave to state authorities in Warsaw on June 17, 1983, John Paul II expressed this when he said: "I will continue to consider as my own every true good of my homeland..." These words recall the words of Piotr Skarga: "Whoever serves his homeland serves himself because all his good [...] is contained in it." 
the ways a person can contribute to the good of his homeland in this study, the Polish bishop's letter acknowledges the following ways in which individuals can contribute: through intergenerational solidarity, responsibility for the fate of the weakest members of society, honesty in daily civic life, and readiness to serve and sacrifice for the sake of the common good. ${ }^{18}$

In another document, the Polish bishops write: "Patriotism is made manifest in our civic attitudes; in respecting the laws and principles that govern social life such as faithfully paying taxes; in our interest in public matters; in responsibly participating in the democratic process; in conscientiously and honestly fulfilling our professional duties; in nurturing our historical memory; in respecting national figures and symbols; in caring for our environment; in our involvement in government and the works of countless organizations; and in taking up various social initiatives." 19 The local bishops said that patriotism is expressed in the details, cultures, customs, and sometimes in the accents or dialects of specific areas or regions. ${ }^{20}$ According to the bishops, "Patriotism today should be expressed in family life, which is the first school of love, responsibility, and service of our neighbor." 21 Love for one's homeland is also "kindness, solidarity, honesty, and interest in building the common good." 22

Striving for the common good can take on many forms. First, it includes one's relationship to truth and forming one's own conscience. ${ }^{23}$

\begin{tabular}{ll}
\hline 18 & See no. 1. \\
19 & Ibid, no. 4. \\
20 & See Ibid. \\
21 & Ibid. \\
22 & Ibid.
\end{tabular}

23 John Paul II spoke about this in his homily in Skoczów, Poland on May 22, 1995: "Today our Homeland faces many difficult social, economic, and political problems. We must solve these problems with wisdom and perseverance. The most fundamental problem that remains, however, is the matter of the moral order. This order is the foundation of the life of every person and every society. Therefore, before all else, Poland calls out today for people of conscience! Be a person of conscience, which primarily means that, even when it is difficult and demanding, you will listen to your conscience in every situation and not stifle its voice within you. This means that you must engage yourself in the good, multiply it within you, and always refuse to accept evil, as St. Paul says, 'Do not be conquered by evil but conquer evil with good' (Roman 12:21)." To be a person of conscience means that you will make demands of yourself, rise up when you have fallen, and continually convert. To be a person of conscience means to be involved in building up God's kingdom-a kingdom of truth and life, of justice, of love and peace in our families, in the societies in which we 
Moral theology

There are also a number of specific attitudes in which patriotism is expressed. For example, striving to be knowledgeable about the history of one's nation signifies patriotism, since it is not possible to serve the good of one's country if a person does not know its history, rich tradition, and culture. ${ }^{24}$ Patriotism is also involvement in developing one's native culture..$^{25}$ Affirming one's entire cultural heritage, respecting and cultivating this heritage, and striving to develop it, all fully express an individual's faithfulness to his roots. ${ }^{26}$ Simple but meaningful gestures, such as perceiving the beauty in one's homeland and educating others in love for one's country, can also be a manifestation of patriotism.

An entire range of virtues associated with patriotism exists. In the Thomistic spirit they could be called cognate virtues, or parts of the virtue of patriotism, which test the authenticity of patriotism. Patriotism, then, is not comprised of one virtue but rather an aggregate of virtues. At the same time, however, the sum of these virtues does not add anything to patriotism. For example, it is very difficult to imagine patriotism without specific attitudes such as: an ability to dialog, truthfulness, justice, solidarity, foresight, courage in undertaking new tasks, and a spirit of participation. Yet, there are always new ways that one can show patriotism: for example, attracting foreign investors, making sure that they are optimally involved in the development of the domestic economy, and considering the origin of products (i.e., selecting local and national brands).

Patriotism is (and should be) a universal attitude that all must have. Patriotism is each person's duty and service that depends on one's particular profession, state in life, and role in society. Although it is not possible to assign certain patriotic attitudes to particular professions, there are specific professions, such as military service, that are innately patriotic. Similarly, diverse political beliefs and views should not lead

live, and in our entire Homeland. To be a person of conscience also means that you will courageously take up your responsibilities for public matters, care for the common good, and not close your eyes to the poverty and needs of your neighbor, in an evangelical spirit of solidarity: "Bear one another's burdens" (Gal. 6:2). Translator's translation.

24 See John Paul II, "Homily,” Łowicz, Poland (June 14, 1999). https://w2.vatican. va/content/john-paul-ii/en/homilies/1999/documents/hf_jp-ii_hom_19990614_lowicz.html.

See John Paul II, "Farewell Speech," Cracow, Poland (June 10, 1997). https:// w2.vatican.va/content/john-paul-ii/en/speeches/1997/june/documents/hf_jpii_spe_19970610_congedo-polonia.html. 
to conflict between citizens and leaders, but rather can and should be subordinated to the common good. Since patriotism is a universal duty, one should constantly learn it and educate others in it. Patriotic education should teach about courageous and humble national figures that have been faithful to ideals and ready to make sacrifices, since such figures are able to elicit in others the most beautiful feelings and attitudes. ${ }^{27}$

\section{A Moral Evaluation of (Anti)Patriotic Attitudes}

There are a variety of sins against love for one's country. For the most part, these sins can be divided into three categories: lack of patriotism, anti-patriotism, and distortions of patriotism, which are often manifested in the following deviations of true patriotism: nationalism, chauvinism, and xenophobia. ${ }^{28}$ As the Polish bishops have emphasized, while modern distortions of patriotism differ among themselves, they all have the following in common: they lack a universal spirit, they are closed to other nations, and they make their own country absolute. From where do these attitudes come? According to the Polish bishops, these attitudes arise from individual and national egoism. Individual egoism entails a person's indifference to the fate of the national community and the exclusive concern for himself and for those closest to him. Similarly, national egoism means closing oneself off to other national communities as well as the universal community. It is important to realize, however, that these words are abused today; for, anyone who speaks of love for his nation and invokes its good is immediately called a nationalist, chauvinist, xenophobe, and (sometimes) fascist. In reality, however, the nationalists, chauvinists, and xenophobes are always the accusers and often right-winged politicians. ${ }^{29}$

27 John Paul II, “Address to Polish Parliament," Warsaw, Poland (June 11, 1999), https://w2.vatican.va/content/john-paul-ii/en/speeches/1999/june/documents/ hf_jp-ii_spe_19990611_warsaw-parliament.html.

Nationalism asserts that the nation is the fundamental social bond and, as such, is not a distortion of patriotism. However, in common parlance, nationalism is wrongly identified with a hostile attitude (chauvinism) and anxiety (xenophobia) towards other peoples. The Polish bishops' letter manifested this unequivocally negative understanding of nationalism.

The titles of Polish media publications that spoke about the Polish bishops' letter confirmed this. For example, Gazeta Wyborcza has an articled entitled "Nie dla kibolskiej agresji na stadionach, pogardy wobec innych, manipulowania historią i banalizowania cierpienia [Not for Aggressive Football Gans: Contempt for Others, the Manipulation of History, and the Trivialization of Suffering];" Rzeczpospolita: "Episkopat ws. patriotyzmu i nacjonalizmu. Biskupi ganią polityków? 
Moral theology

A lack of patriotism, or apathy toward one's country and an inability to perceive the situations of one's homeland (its successes and problems) objectively, is also a sin. A lack of a sense of belonging to one's homeland, distancing oneself from one's nation, and seeking one's own or a group's good before the good of one's nation are also sins. Anti-education is also antipatriotic. Such negative attitudes as ignoring one's country's rich heritage (language, common culture, etc.) and indifference to the fate of one's countrymen are also sins against charity and the Fourth Commandment: "Honor your mother and your father."

Antipatriotic attitudes and actions such as treason, ridiculing patriotic figures, whistle blowing, complaining about one's country, and delight in its defeat are particularly worthy of condemnation. If love is the greatest commandment, then everything that opposes love is the gravest of sins. If love is the essence of patriotism, then a lack of patriotism or, even more, antipatriotic actions and attitudes compromise the very essence of Christianity.

Patriotism has a moral dimension. As they love their mother, citizens should love their homeland in a special way and fulfill particular duties toward it. It is incredibly difficult, however, to create a list of particular moral obligations that, when fulfilled, demonstrate patriotism. This difficulty arises from the fact that the world is changing, and this change brings with it a new challenges. For this reason, moral theology is open to other sciences that continually provide new data. From a moral point of view, true patriotism is always love and respect for one's homeland-a love and respect that seek new forms of expression, particularly if one's homeland is in a particular situation. The tenet ordo caritatis requires that a person should give his homeland

[The Episcopate vs. Patriotism and Nationalism: Are the Bishops Criticizing Politicians?]"; Newsweek: "Biskupi w końcu zabierają głos: Nacjonalizm jest przeciwieństwem patriotyzmu [The Bishops Are Speaking Out: Patriotism is the Opposite of Nationalism];" Tok.fm: "Biskupi wytknęli władzy, że sianie nienawiści jest niechrześcijańskie [The Bishops Have Indicated that Hatred Is Unchristian];" Fakt: "Biskupi piszą list i ganią polityków. Padły mocne słowa [The Bishops have Spoken: Their Letter Criticizes Politicians];" the site naTemat. $p l$ : "Postawą niechrześcijańską jest egoizm narodowy i nacjonalizm [National Egoism and Nationalism: UnChristian Attitudes];" "Episkopat uderza w prawice i "prawdziwych Polaków [The Polish Bishop's Conference has Struck the Right and 'True Poles'];" J. Hartman: The Polish Bishops' letter about patriotism is a "a huge achievement for liberal democratic ethics." 
precedence in the order of love and never give into the temptation to fail to love or, even worse, hate it.

\section{MORALNY WYMIAR PATRIOTYZMU}

Pełny opis patriotyzmu domaga się wieloaspektowego spojrzenia, w którym nie może zabraknąć kwestii moralnych. Specyfiką teologicznomoralnego podejścia do miłości ojczyzny jest określenie zobowiązującego charakteru i źródeł tej postawy, jej konkretnych przejawów oraz ocena moralna postaw (anty)patriotycznych. Obowiązek patriotyzmu ma swoje źródło w wiarze, nadziei oraz powszechnej i zarazem uporządkowanej miłości, której dotyczy IV przykazanie Dekalogu. Praktyczna realizacja tej powinności dokonuje się poprzez szereg postaw szczegółowych, które wyrażają nastawienie uczuciowe oraz praktyczną służbę dobru ojczyzny. Wszystko zaś to, co się sprzeciwia patriotyzmowi (jego brak, wypaczenia czy postawy wprost antypatriotyczne) stanowi ciężkie wykroczenie moralne. Uzasadnieniem dla takiej kwalifikacji jest centralny charakter miłości w moralności chrześcijańskiej.

Słowa kluczowe: ojczyzna, patriotyzm, moralność.

\section{Bibliography:}

1. Bartyzel, J. "Patriotyzm." Encyklopedia katolicka, Vol. 15. Edited by E. Gigilewicz. Lublin, 2011.

2. Catechism of the Catholic Church. Vatican City, Italy: Libreria Editrice Vaticana, 1997.

3. John Paul II. "Homily." March 6, 1991, Kielce, Poland.

4. John Paul II. "Homily." June 14, 1999, Łowicz, Poland. https:// w2.vatican.va/content/john-paul-ii/en/homilies/1999/documents/hf_jpii hom 19990614 lowicz.html.

5. John Paul II. "Homily." May 22, 1995, Skoczów, Poland.

6. John Paul II. "Speech to the Public Authorities at the Belvedere Palace." June 17, 1982, Warsaw, Poland. https://w2.vatican.va/content/john-paul-ii/ en/speeches/1983/june/documents/hf_jp-ii_spe_19830617_autorita-statali. html

7. John Paul II. "Welcome Address at Okiecie Airport." June 16, 1983, Warsaw, Poland.

8. John Paul II. "Departure Address at the Cracow Airport." June 10, 1997, Cracow, Poland. https://w2.vatican.va/content/john-paul-ii/en/speeches/1997/june/documents/hf jp-ii spe 19970610 congedo-polonia.html.

9. Jan Paweł II, "Address to Polish Parliament." June 11, 1999, Warsaw, Poland. https://w2.vatican.va/content/john-paul-ii/en/speeches/1999/june/ documents/hf_jp-ii_spe_19990611_warsaw-parliament.html.

10. John Paul II. "Address to the United Nations." The Fiftieth General Assembly of the United Nations Organization. October 5, 1995, United 
Moral theology
Nations Headquarters, New York. Speech. https://w2.vatican.va/content/ john-paul-ii/en/speeches/1995/october/documents/hf_jp-ii_spe_05101995 address-to-uno.html.

11. Kluxen-Pyta, D. "Patriotismus." Lexikon für Theologie und Kirche. Edited by K. Baumgartner. Freiburg, Basel, Rome, Vienna: 1998): 1,470.

12. Leo XIII. Encyclical: Sapientiae christianae. Vatican City, Italy: Libreria Editrice, 1890.

13. Niemiec, B. "Patriotyzm." In Jan Pawet II. Encyklopedia nauczania społecznego. Edited by A. Zwoliński. Radom: Wydawnictwo Polwen, 2003, 353-356.

14. Paul VI, Pastoral Constitution on the Church in the Modern World: Gaudium et spes. Vatican City, Italy: Libreria Editrice Vaticana, 1965.

15. Pawłowicz, J. Patriotyzm jako podstawa ładu społecznego $w$ nauczaniu Kościoła katolickiego. http://www.kuria-dodatek.szczecin.opoka.org.pl/ patriotyzm.htm. Accessed: 06.01.2017.

16. Pius X. Encyclical on St. Anselm Aosta: Communium Rerum. Vatican City, Italy: Libreria Editrice Vaticana, 1909.

17. Pius XII. Encyclical on the Unity of Human Society: Summi Pontificatus. Vatican City, Italy: Libreria Editrice Vaticana, 1939.

18. Polish Conference of Catholic Bishops, Letter Chrześcijański ksztatt patriotyzmu. March 14, 2017, no. 1.

19. Przesmycki, P. "Patriotyzm w nauczaniu Kościoła katolickiego.” Annales. Etyka w życiu gospodarczym 11, no. 2 (2008): 195-203.

20. Salij, J. Patriotyzm dzisiaj. Poznan: W Drodze, 2005.

21. Skorowski, H. Być chrześcijaninem i obywatelem dziś. Refleksje o postawach moralno-spotecznych. Warsaw: 1994.

22. Second Vatican Council. Decree on the Mission Activity of the Church: Ad gentes divinitus. Vatican City, Italy: Libreria Editrice Vaticana, 1965.

23. Zadykowicz, T. "O nowe oblicze patriotyzmu. Refleksja nad nauczaniem Jana Pawła II do Polaków.” Roczniki Teologiczne, Vol. 52, no. 3 (2005): 145-157.

24. Zadykowicz, T. "Patriotyzm jako postawa." Etyka żotnierska. Etyka w stużbie ojczyźnie. Edited by K. Jeżyna, J. Gałkowski, and M. Kalinowski. Warsaw: Wydawnictwo Ministerstwa Obrony Narodowej, 2008, 53-58.

25. Zadykowicz, T. "Umiłowanie ojczyzny i patriotyzm," Etyka żotnierska. Etyka w stużbie ojczyźnie. Edited by K. Jeżyna, J. Gałkowski, and M. Kalinowski. Warsaw: Wydawnictwo Ministerstwa Obrony Narodowej, 2008, 73-85. 